\title{
COSC-1 - drilling of a subduction-related allochthon in the Palaeozoic Caledonide orogen of Scandinavia
}

\author{
H. Lorenz ${ }^{1}$, J.-E. Rosberg ${ }^{2}$, C. Juhlin ${ }^{1}$, L. Bjelm ${ }^{2}$, B. S. G. Almqvist ${ }^{1}$, T. Berthet ${ }^{1}$, R. Conze ${ }^{3}$, D. G. Gee ${ }^{1}$, \\ I. Klonowska ${ }^{1}$, C. Pascal ${ }^{4}$, K. Pedersen ${ }^{5}$, N. M. W. Roberts ${ }^{6}$, and C.-F. Tsang ${ }^{1,7}$ \\ ${ }^{1}$ Department of Earth Sciences, Uppsala University, Villavägen 16, 75236 Uppsala, Sweden \\ ${ }^{2}$ Engineering Geology, Lund University, John Ericssons väg 1, 22100 Lund, Sweden \\ ${ }^{3}$ GFZ German Research Centre for Geosciences, Telegrafenberg, 14473 Potsdam, Germany \\ ${ }^{4}$ Institute of Geology, Mineralogy and Geophysics, Ruhr-University Bochum, Universitätsstraße 150, \\ 44780 Bochum, Germany \\ ${ }^{5}$ Department of Civil and Environmental Engineering, Chalmers University of Technology, \\ 41296 Gothenburg, Sweden \\ ${ }^{6}$ NERC Isotope Geosciences Laboratory, British Geological Survey, Nottingham, NG12 5GG, UK \\ ${ }^{7}$ Lawrence Berkely National Laboratory, Earth Sciences Division, 1 Cyclotron Road, MS74R316C, \\ Berkeley, CA 94720, USA
}

Correspondence to: H. Lorenz (henning.lorenz@geo.uu.se)

Received: 13 February 2015 - Revised: 24 April 2015 - Accepted: 5 May 2015 - Published: 29 May 2015

\begin{abstract}
The Collisional Orogeny in the Scandinavian Caledonides (COSC) scientific drilling project focuses on mountain building processes in a major mid-Palaeozoic orogen in western Scandinavia and its comparison with modern analogues. The project investigates the subduction-generated Seve Nape Complex. These in part under ultra-high-pressure conditions metamorphosed outer continental margin and continent-ocean transition zone assemblages were emplaced onto the Baltoscandian platform and there influenced the underlying allochthons and the basement. COSC-1 is the first of two ca. $2.5 \mathrm{~km}$ deep, fully cored drill holes located in the vicinity of the abandoned Fröå mine, close to the town of Åre in Jämtland, central Sweden. It sampled a thick section of the lower part of the Seve Complex and was planned to penetrate its basal thrust zone into the underlying lowergrade metamorphosed allochthon. The drill hole reached a depth of $2495.8 \mathrm{~m}$ and nearly $100 \%$ core recovery was achieved. Although planning was based on existing geological mapping and new high-resolution seismic surveys, the drilling resulted in some surprises: the Lower Seve Nappe proved to be composed of rather homogenous gneisses, with only subordinate mafic bodies, and its basal thrust zone was unexpectedly thick (> $800 \mathrm{~m})$. The drill hole did not penetrate the bottom of the thrust zone. However, lower-grade metasedimentary rocks were encountered in the lowermost part of the drill hole together with garnetiferous mylonites tens of metres thick. The tectonostratigraphic position is still unclear, and geological and geophysical interpretations are under revision. The compact gneisses host only eight fluid conducting zones of limited transmissivity between $300 \mathrm{~m}$ and total depth. Downhole measurements suggest an uncorrected average geothermal gradient of $\sim 20^{\circ} \mathrm{C} \mathrm{km}^{-1}$. This paper summarizes the operations and preliminary results from COSC-1 (ICDP 5054-1-A), drilled from early May to late August 2014, and is complemented by a detailed operational report and the data repository.
\end{abstract}




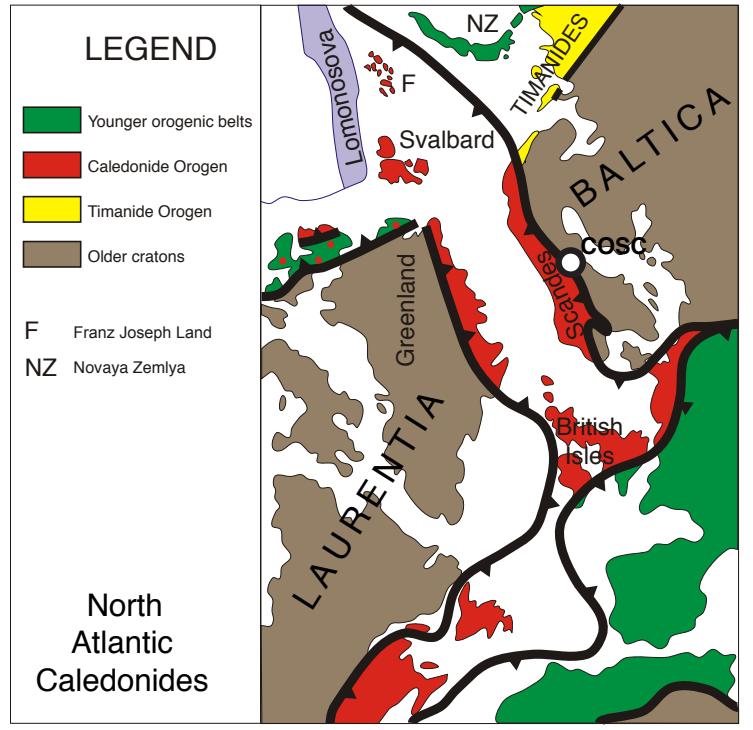

Figure 1. The Caledonides prior to opening of the North Atlantic Ocean. Modified from Lorenz et al. (2012).

\section{The Caledonides - the world's major mid-Palaeozoic mountain belt}

The Caledonides of western Scandinavia and eastern Greenland (Fig. 1) have long been recognized to have been part of a collisional orogen of Alpine-Himalayan dimensions, essentially the result of the closure of the Iapetus Ocean during the Ordovician and subsequent underthrusting of continent Laurentia by Baltica in the Silurian and Early Devonian during Scandian collisional orogeny. Several hundreds of kilometres of thrust emplacement of allochthons have been demonstrated, E-directed in the Scandes and Wdirected in Greenland. In both the Scandinavian and Greenland Caledonides, the allochthons that originated from the outer parts of the continental margins were subjected to highgrade metamorphism and emplaced, apparently hot, onto the adjacent platforms (cf. Gee et al., 2008). Baltica, as the smaller of the two palaeo-continents involved in the collision (referred to as Scandian orogeny in the North Atlantic region), played a similar role to that of India in the presentday Himalaya-Tibet context. The Scandinavian Caledonides comprise thrust sheets transported onto the Palaeozoic platform successions of the Baltoscandian margin of Baltica (Fig. 2). The Caledonian front is marked by a sole thrust that dips $1-2^{\circ}$ westwards beneath the orogen, underlain by a thin veneer of Cambrian (locally Ediacaran) sedimentary rocks that unconformably overlie Proterozoic crystalline basement. The thrust sheets are subdivided into the Lower, Middle, Upper and Uppermost allochthons (Gee et al., 1985). The Lower Allochthon (Jämtlandian Nappes) is dominated by a sedimentary succession of Neoproterozoic and Cambro-Silurian strata, featuring westerly-derived tur-
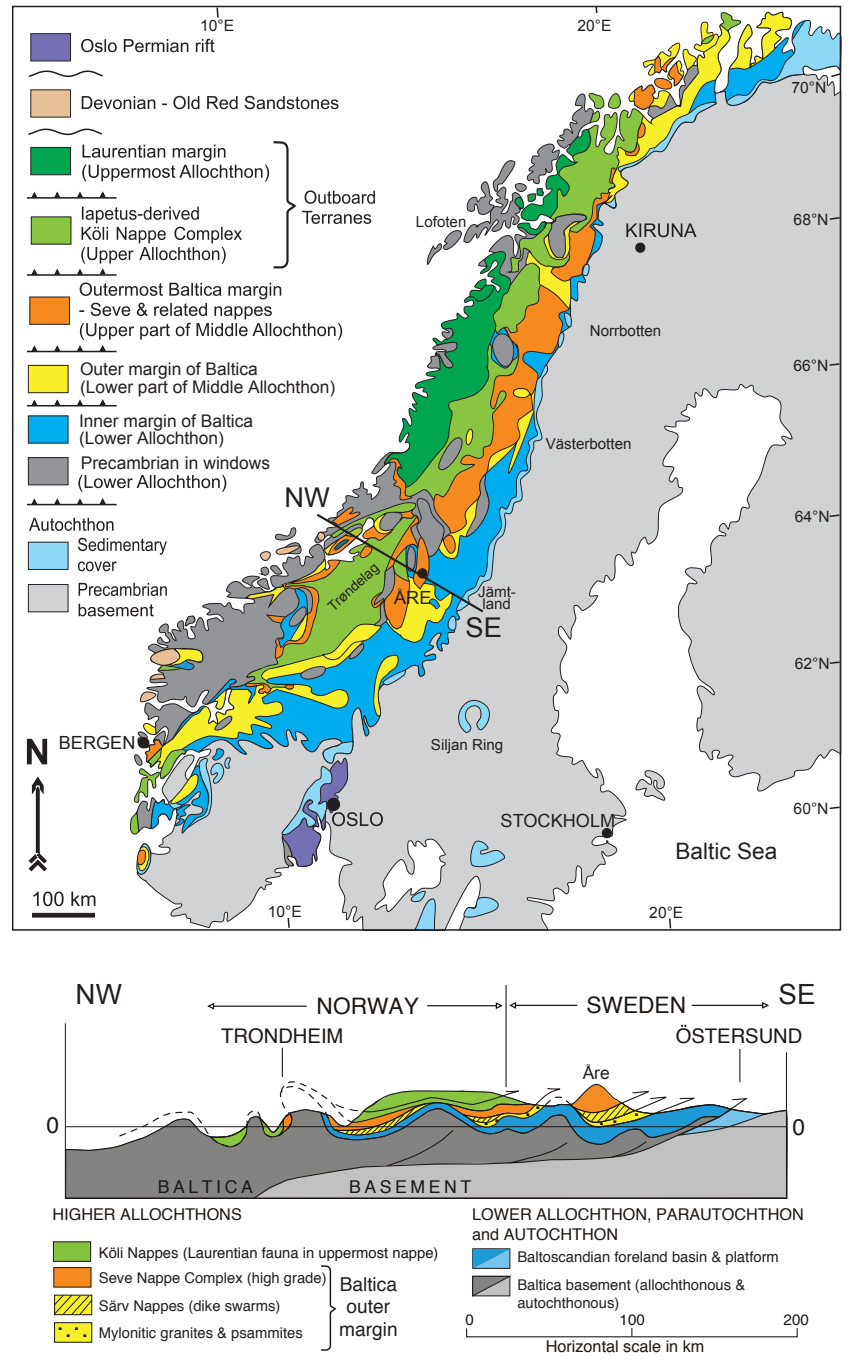

Figure 2. Tectonostratigraphic map of the Scandinavian Caledonides and sketch section along the geotraverse from Östersund to the Norwegian coast. Modified from Gee et al. (2010).

bidites in the Ordovician and Silurian. Only minor basementderived units are incorporated in eastern parts of this allochthon (Greiling et al., 1998), but towards the west, seismic profiling suggests that the basal decollement passes beneath the crystalline basement exposed in windows (Palm et al., 1991; Juhojuntti et al., 2001). The Middle Allochthon is of higher metamorphic grade than the underlying units (Andréasson and Gorbatschev, 1980). In most areas it contains a basal basement-derived thrust sheet (e.g. the Tännes Augen Gneiss Nappe), overlain by greenschist facies Offerdal Nappe metasandstones, composing the footwall for the remarkable Särv Nappe (Strömberg, 1961) with its abundant ca. 600 Ma dolerite dyke swarms. The sedimentary host rocks are composed of Neoproterozoic sandstones with subordinate carbonates and tillites (Kumpulainen, 1980). The uppermost tectonic unit in the Middle Allochthon (Andréas- 
son and Gee, 2008; Gee et al., 2008), previously included in the Upper Allochthon, is the Seve Nappe Complex, composed in most areas of three units (Sjöström, 1983; van Roermund, 1985; Bergman and Sjöström, 1997): a lower part of similar protolith to the Särv Nappe, but ductilely deformed in amphibolite (locally eclogite) facies; a central part (e.g. Åreskutan Nappe) of migmatites and paragneisses (Arnbom, 1980) with a previous ultra-high-pressure metamorphic history (Klonowska et al., 2015); and an upper, amphibolite-dominated unit with micaschists and psammites. The high-grade metamorphism and leucogranite intrusions of the Seve Nappes have yielded Early Silurian ages (Gromet et al., 1996; Williams and Claesson, 1987; Ladenberger et al., 2014). The entire Middle Allochthon was derived from west of the Norwegian coast and the upper units transported at least $400 \mathrm{~km}$ eastwards during Scandian orogeny (Gee, 1978). The tectonostratigraphically highest rocks in Jämtland are the Köli Nappes in the Upper Allochthon. This low to high greenschist facies unit contains basal slices of ophiolite (e.g. at Handöl) and is dominated by sedimentary rocks of Early Palaeozoic age (Kulling, 1933). The Uppermost Allochthon, metasedimentary and carbonate rocks inferred to be derived from the Laurentian margin are only exposed farther to the northwest in the mountain belt.

\section{Scientific objectives}

The COSC project aims to study mountain building processes at mid-crustal levels in a major orogen, in particular the transport and emplacement of subduction-related highgrade allochthons with a focus on the Seve Nappe Complex. During the last 4 years of preparation for the drilling, following the initial COSC workshop in 2010 (Lorenz et al., 2011), investigations of the Seve Nappe Complex in the Jämtland area have improved our understanding of the subduction systems that existed along the Baltoscandian margin during Ordovician closure of the Iapetus Ocean. Ultra-high-pressure metamorphism was recognized in both the lower and middle parts of the Seve Nappe Complex in northern Jämtland (Janák et al., 2013) and the Middle Ordovician age confirmed (Root and Corfu, 2012). In central Jämtland, both in the Åreskutan Nappe and $50 \mathrm{~km}$ farther west in the correlative Snashögarna Nappe (Majka et al., 2014; Klonowska et al., 2015), microdiamonds were discovered in garnets of the "granulite facies" migmatitic gneisses. These discoveries have profound implications for our understanding of Caledonian orogeny in Scandinavia and for the interpretation of high-grade rocks in the orogen, particularly those in the deeper structural levels of the hinterland (e.g. in the Western Gneiss Region of southern Norway) where basement and allochthonous cover were subducted a second time in the Early Devonian, during the final phases of Scandian collision.
Topical working groups developed the scientific objectives of the COSC scientific drilling project. Major targets are the following:

- to establish a coherent model of mid-Palaeozoic (Scandian) mountain building and to apply these new insights to the interpretation of modern analogues, in particular the Himalaya-Tibet mountain belt;

- to determine the origin of observed seismic reflections and constrain geophysical interpretations in order to use this information to further our understanding of the geological structure of the mountain belt and the Fennoscandian basement;

- to refine knowledge on climate change at high latitudes, including historical global changes, recent palaeoclimate development (since last ice age);

- to understand the hydrological characteristics of the geological units and research present groundwater circulation patterns of the mountain belt;

- to analyse the extent, functions and diversity of microorganisms in the drill hole as a function of the different penetrated geological strata and their depth.

\section{Strategy}

Two wireline fully cored drill holes, each to ca. $2.5 \mathrm{~km}$ depth, can penetrate through the tectonic stack from the high-grade Lower Seve Nappe and well into the Baltican basement. COSC-1, near Åre, was finished during 2014 (this paper) and has a focus on the Middle Allochthon with its inverted metamorphic gradient, thick ductile shear zones and mylonites (Fig. 3). At the top of the mountain Åreskutan, ultrahigh-pressure gneisses of the Åreskutan Nappe are exposed (Klonowska et al., 2015). These rocks can be followed downwards, along the slopes of Areskutan into the underlying, amphibolite facies gneisses of the Lower Seve Nappe. There, the COSC-1 borehole is located and provides a nearly complete section through the Lower Seve Nappe and into the underlying thrust zone. COSC-2 will begin drilling in units of similar tectonostratigraphic position as those encountered in the deepest parts of COSC-1. Thus, its geographical location will be farther east towards the thrust front. COSC-2 will investigate the composition, metamorphism and structure of the Lower Allochthon, the basal decollement, footwall alum shale and underlying Precambrian basement (Fig. 3).

\section{Technical operations}

This paper is complemented by the COSC-1 operational report with detailed explanations at doi:10.2312/ICDP.2015.002 (Lorenz et al., 2015a). 
Table 1. Location of the boreholes on the COSC-1 drill site obtained by differential GPS, geodetic datum WGS84 (EPSG:4326).

\begin{tabular}{lccccc}
\hline Name & Designation & Driller's depth $(\mathrm{m})$ & Latitude & Longitude & Elevation (m a.s.1.) \\
\hline COSC-1 & $5054-1-\mathrm{A}$ & 2495.8 & $63.401629^{\circ} \mathrm{N}$ & $013.202926^{\circ} \mathrm{E}$ & 522.8 \\
Observation 1 & $5054-1-\mathrm{B}$ & 100 & $63.401788^{\circ} \mathrm{N}$ & $013.202924^{\circ} \mathrm{E}$ & 522.5 \\
Observation 2 & $5054-1-\mathrm{C}$ & 50 & $63.401762^{\circ} \mathrm{N}$ & $013.202819^{\circ} \mathrm{E}$ & 522.5 \\
\hline
\end{tabular}

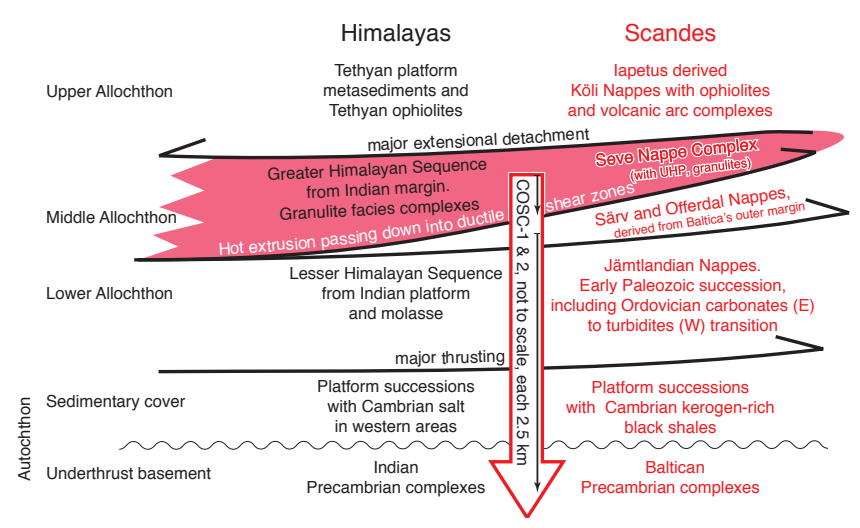

Figure 3. Schematic comparison of tectonostratigraphic units between Himalayas and Scandes with COSC-1 and COSC-2 indicated.

To determine the optimal location for the COSC-1 drill site (Fig. 4), a high-resolution reflection seismic survey was carried out in 2010 and extended in 2011. Details on the 2010 survey can be found in Hedin et al. (2012). The scientific criterion for the selection of the drill site was to sample an as-thick-as-possible section of the Lower Seve Nappe before penetrating through the thrust zone and into the underlying nappes. Technical criteria were accessibility, infrastructure and a good relationship with the land owner, Åre municipality.

The drill site occupies an area of approximately $1050 \mathrm{~m}^{2}$ $(30 \mathrm{~m} \times 35 \mathrm{~m}$, Fig. 5) and is constructed of compacted soil material covered by angular rocks separated with a geotextile as barrier. A circular cellar construction was built by placing two concrete rings, inner diameter $1.2 \mathrm{~m}$, around the position for the planned COSC-1 borehole (5054-1-A). Initially a $3 \mathrm{~m}$ long surface casing with an outer diameter (OD) of $193.8 \mathrm{~mm}$ and an inner diameter (ID) of $183.8 \mathrm{~mm}$ was installed. Thereafter a hole with $165 \mathrm{~mm}$ diameter was drilled down to $103 \mathrm{~m}$ using a 5-inch down-the-hole (DTH) hammer and the conductor casing (OD $139.7 \mathrm{~mm} / \mathrm{ID} 129.7 \mathrm{~mm}$ ) installed and cemented from the bottom to the surface.

Two additional drill holes to $100 \mathrm{~m}$ (5054-1-B) and $50 \mathrm{~m}$ (5054-1-C), respectively, were drilled, equipped with seismometers and cemented for passive monitoring of the drilling operations. The exact locations of all drill holes are given in Table 1.

Drilling operations started on 1 May 2014 and were completed on 26 August 2014. Drilling operations were con- ducted $24 \mathrm{~h} \mathrm{day}^{-1}$ with initially two drillers per $12 \mathrm{~h}$ shift and three drillers below $545 \mathrm{~m}$ depth (after 2 weeks of drilling). The total depth (TD) of COSC-1 is $2495.8 \mathrm{~m}$.

Drilling was conducted with the Swedish national research infrastructure for scientific drilling ("Riksriggen") at Lund University, Sweden. The well head included a $5^{\prime \prime}$ annular blow out preventer (BOP; Fig. 6), and the mud tanks had a volume of ca. $20 \mathrm{~m}^{3}$. The drill rig (Fig. 7) can handle the three common sizes $P, H$ and $N(123 / 85 \mathrm{~mm}, 96 / 63 \mathrm{~mm}$ and $76 / 48 \mathrm{~mm}$ hole/core diameter) with depth capacities of around 1050, 1600 and $2500 \mathrm{~m}$, respectively. Three core barrel assemblies were deployed (inner tube sample length, core diameter, hole diameter):

- $H$-size triple tube $(3 \mathrm{~m} / 61 \mathrm{~mm} / 96 \mathrm{~mm})$;

- $N$-size triple tube $(3 \mathrm{~m} / 45 \mathrm{~mm} / 75.7 \mathrm{~mm})$;

- $N$-size double tube $(6 \mathrm{~m} / 47.6 \mathrm{~mm} / 75.7 \mathrm{~mm})$.

A double-tube core barrel assembly consists of an outer tube (drill string) with an inner tube (core barrel) that captures the core sample. The triple tube has an additional split tube ("core liner") placed inside of the inner tube for protection of the drill core. The inner tube is equipped with a spearhead and release mechanism at the top for retrieval and with a core lifter at the bottom. The drill bit and reamers are attached to the outer tube.

For HQ3 core drilling (103-1616 m), light-weight drill rods with reinforced threads (HRQ V-wall) were employed together with diamond-impregnated drill bits and surface set reamers. Below $770 \mathrm{~m}$, a so-called rod reamer was attached between the core barrel assembly and the drill rods. The drilling fluid down to $500 \mathrm{~m}$ was fresh water. From 500 to $1616 \mathrm{~m}$ a bio-degradable polymer was added to reduce the friction between the drill string and the borehole walls and to improve the removal of cuttings. After HQ3 drilling was completed, the HRQ-drill string was installed as temporary casing from surface down to $1616 \mathrm{~m}$ : the casing/drill string was not cemented to allow for removal after drilling was finished. Drilling continued with an $N$-size triple-tube core barrel assembly (NQ3, 1616-1709 $\mathrm{m}$ and drill rods (NRQ $\mathrm{V}$-wall) and bits comparable to those used during $H$-size drilling. A standard reamer was placed above the drill bit and a surface set adapter coupling replaced the standard adapter coupling above the core barrel assembly. Below $1709 \mathrm{~m}$, a double-tube core barrel assembly (NQ) was deployed, which increased the sample length from 3 to $6 \mathrm{~m}$ for each core run in 


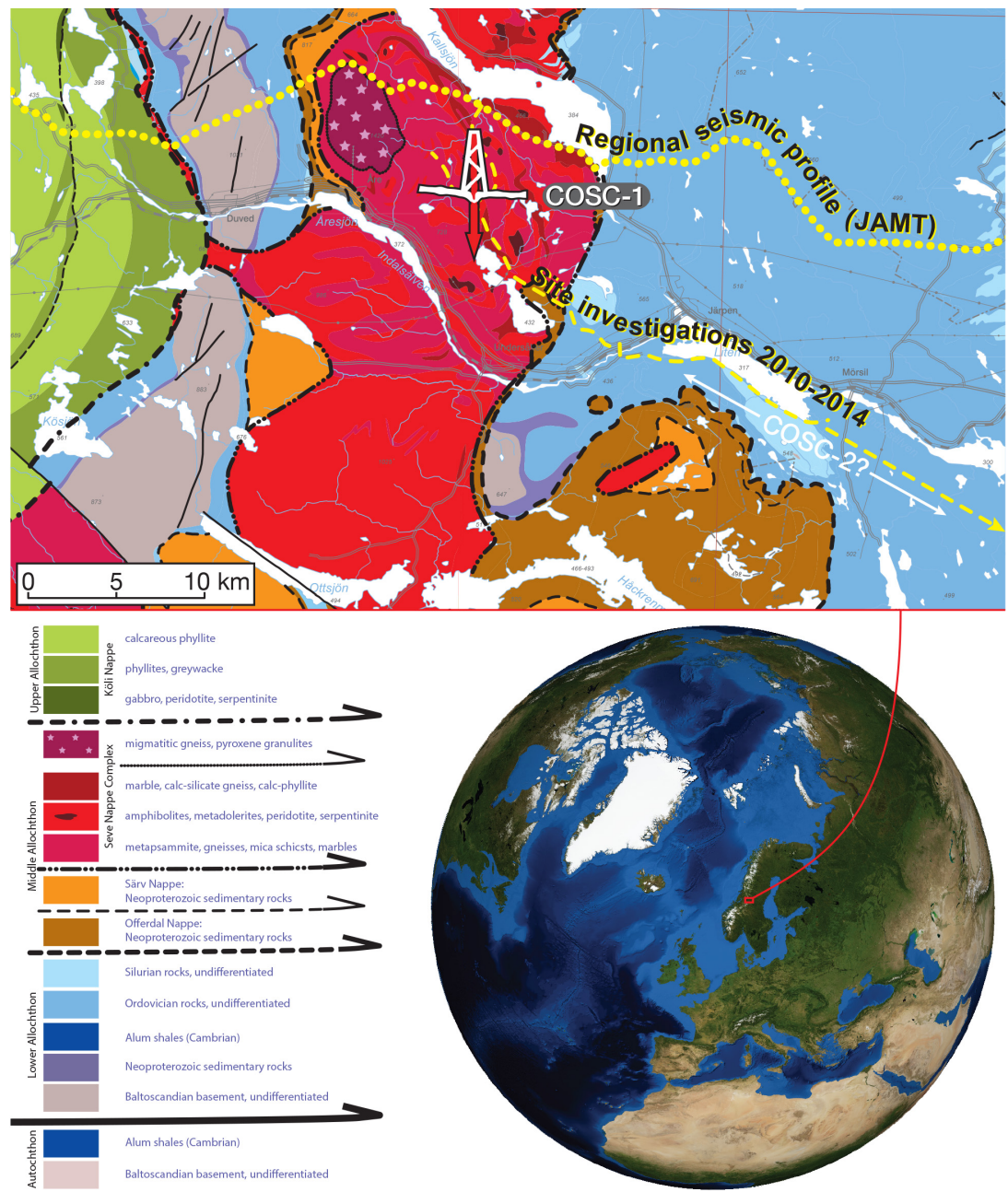

Figure 4. Tectonostratigraphic map of the Åre-Järpen area (based on the 1:200000 scale geological map by the Geological Survey of Sweden). The map shows the COSC-1 drill site and relevant geophysical surveys in relationship to the tectonic units of the Scandinavian Caledonides.

order to save time (30-40\% faster). At $1965 \mathrm{~m}$, the NRQ Vwall drill string was replaced with standard NRQ drill rods. Below $2000 \mathrm{~m}$ a second polymer was added to the mud to reduce friction.

After reaching TD the NRQ-drill string was placed on the bottom of the hole and disconnected at the surface. Thereafter the HRQ-drill string (the temporary casing) was successfully retrieved and the mud column replaced with fresh water through the NRQ-drill string. An end of hole deviation survey was conducted while the NRQ-drill string was pulled out of the hole. The drill hole has very small deviation (Fig. 8). It is only cased down to $103 \mathrm{~m}$ and below left as an open-hole completion. Despite a major problem with deformed drill rods and resulting problems with friction in the borehole, the target depth was reached - however, with a considerable delay because of slower penetration rates and more frequent round trips to replace the quickly worn-out drill bit. Unfortunately, dedicated triple-tube drilling for mi- crobial samples had to be omitted because of the switch to faster double-tube drilling.

\section{Scientific operations}

The on-site scientific work was performed in two $12 \mathrm{~h}$ shifts per day. Normally, three scientists were on site at any time during the operational phase. The complete on-site scientific work from mobilization to demobilization is estimated to about 4.75 man-years. The core-handling procedure by the on-site science team (Fig. 9) was conducted under rigorous control of top and bottom, and the resulting data sets are detailed below. On-site sampling of the drill core was very restricted and only permitted for the studies of thermal conductivity in relation to time after drilling (sample to be returned), matrix gas extraction and analysis (samples have been returned), and microbiology (destructive). All samples in the COSC scientific drilling project are marked with an Inter- 


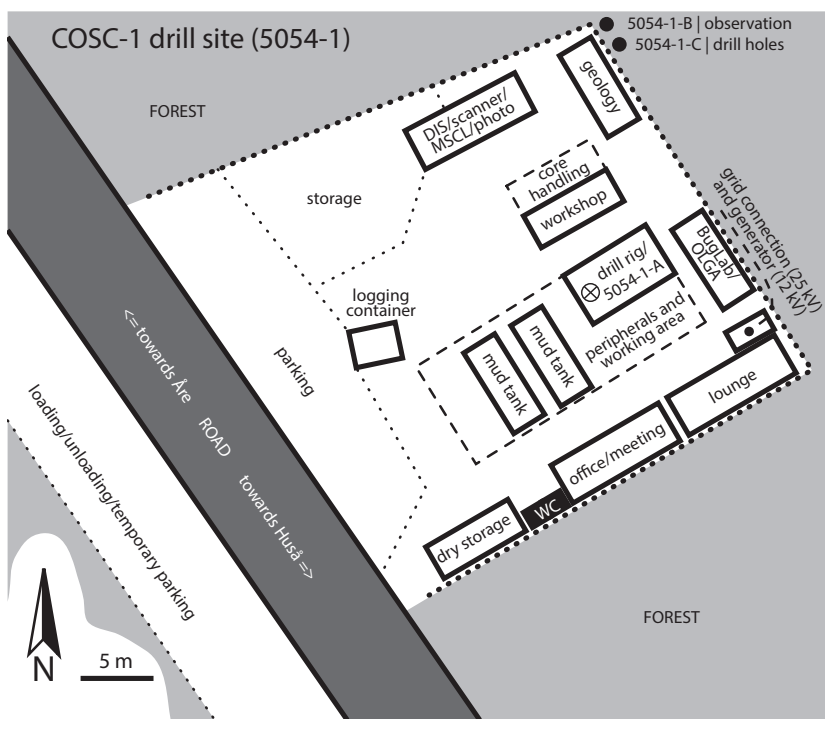

Figure 5. Sketch of the COSC-1 drill site. The working area of the drill site is nearly quadratic with an area of about $1050 \mathrm{~m}^{2}$. The drill rig, the combined mud tanks and manual pipe handling system and some peripherals such as workshop and mud mixer formed the central part of the drill site. In immediate proximity to the northwest, the BugLab container (Mangelsdorf and Kallmeyer, 2010) was located. It hosted OLGA, the online gas monitoring system (Erzinger et al., 2006; Wiersberg and Erzinger, 2011), and provided space for microbiological work and mud sampling. The southeastern part of the drill site was occupied by common facilities and office space. In the northern quarter of the drill site, the on-site science was located. The remaining space was used as storage space for drill rods, logging equipment, and drill core and for parking.

national GeoSample Number (IGSN), a hierarchical unique identifier that is used to track samples and relationships between samples (see also www.geosamples.org/igsnabout).

Due to the relative simplicity of the mud composition, mud logging was restricted to $\mathrm{pH}$, temperature and conductivity measurements every $4 \mathrm{~h}$. Samples were taken every $8 \mathrm{~h}$ and are archived together with the drill core. The On-Line GAs monitoring system (OLGA; Erzinger et al., 2006) was for the first time deployed to qualitatively analyse mud gasses in a slim hole and diamond core drilling project. Despite the substantially different parameters when compared to oil-fieldtype drilling, in which the system had successfully been employed before (Wiersberg and Erzinger, 2011), this experiment was a success.

Several logging campaigns were performed during drilling breaks to secure data in case of a hole loss while drilling and complemented by a comprehensive post-drilling downhole logging programme. Unfortunately, not all instruments were available due to technical problems. A major post-drilling seismic survey was carried out in and around the COSC-1 drill hole, including vertical seismic profiling (VSP) in the drill hole, a sparse 3-D survey centred on the drill hole and three long-offset profiles centred on the drill hole equipped

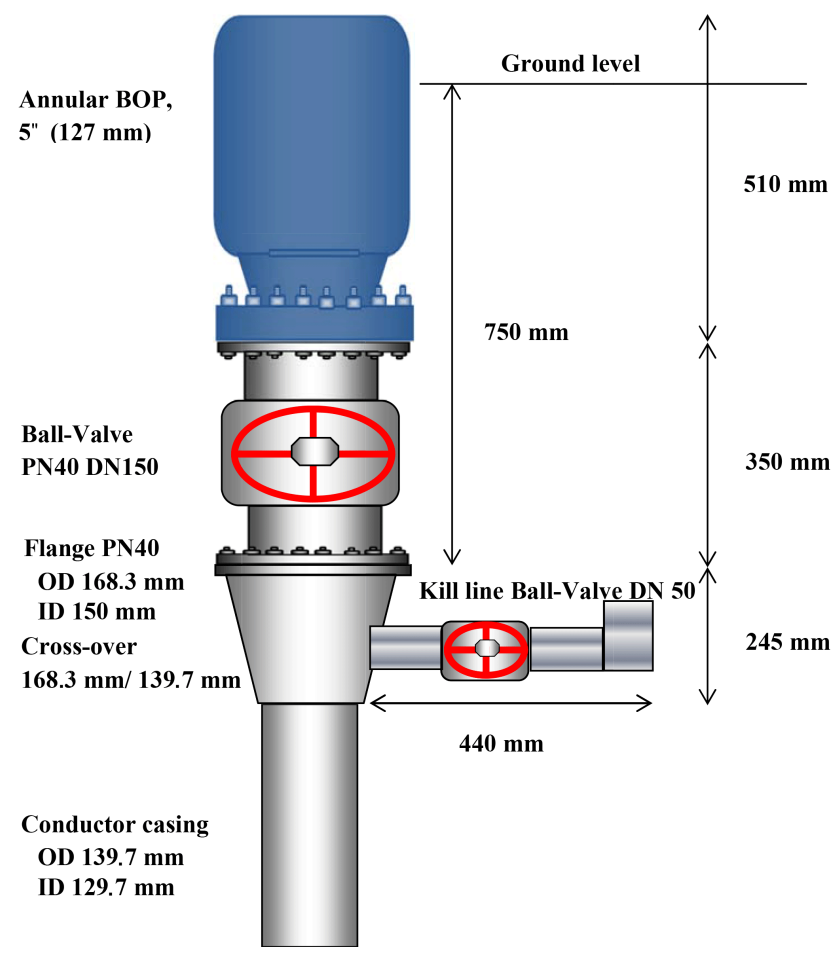

Figure 6. Sketch of the COSC-1 wellhead. A $5^{\prime \prime}$ annular blow out preventer (BOP) was attached on top of the main valve, a DN150 ball valve. A DN50 ball valve was used for the kill line.

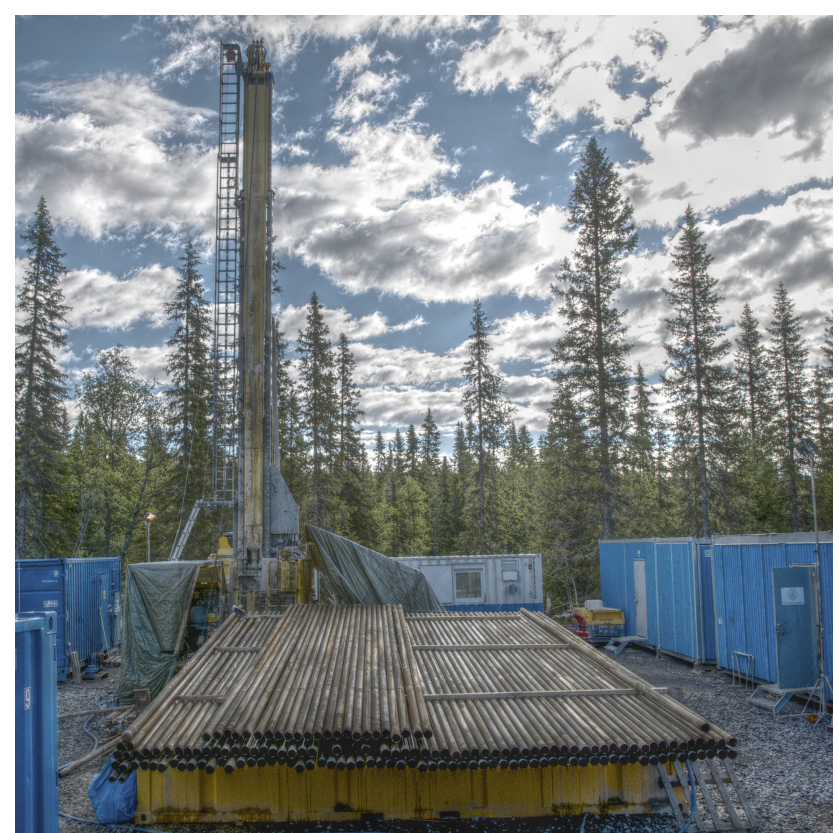

Figure 7. The Swedish national research infrastructure for scientific drilling, "Riksriggen". An Atlas Copco CT20C crawler mounted drill rig with a manual pipe handling system mounted on top of the mud tanks, with ca. $1400 \mathrm{~m}$ of HRQ drill pipe in this photograph. 


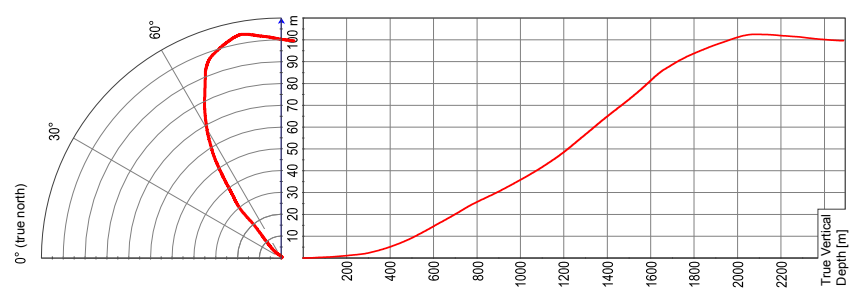

Figure 8. The COSC-1 drill hole deviation, seen from above (with azimuth) and plotted vs. depth: $10 \times$ horizontal exaggeration.

with $153 \mathrm{C}$ geophones. The data from this survey will be published elsewhere.

\section{Drill core}

According to the scientific documentation, $2396.0 \mathrm{~m}$ of the drill core was recovered, resulting in a core recovery of $100.12 \%$. The content of two inner tubes was lost in the drill hole because of malfunctioning core catchers and had to be "over-drilled" in order to retrieve it. In total, approx. $2.5 \mathrm{~m}$ of the drill core was unaccounted for (i.e. documented core loss).

Down to about $1800 \mathrm{~m}$, the COSC-1 drill hole penetrated a succession that is dominated by gneisses of varying compositions (felsic, amphibole, calc-silicate, other), often garnet and diopside bearing. Metagabbros and amphibolites are common and apparently correlate with seismic reflections between 500 and $1000 \mathrm{~m}$ depth. Also marbles, pegmatite dykes and minor mylonites occur. These rocks are highly strained. Small-scale structures (e.g. isoclinal folding) are occasionally discernible in the narrow section provided by the drill cores. (Young) Fractures are sparse. One obviously fluid-conducting set of very steep fractures results in dissolution of calcite-rich bands in the gneisses to form "microkarst" (at about $175 \mathrm{~m}$ and several levels between 1200 and $1320 \mathrm{~m})$.

First signs of increasing strain appear shortly below $1700 \mathrm{~m}$ in the form of narrow deformation bands and thin mylonites. The mylonites increase in thickness to around $1 \mathrm{~m}$ between 1900 and $2000 \mathrm{~m}$. Below ca. $2100 \mathrm{~m}$, mylonites dominate and garnets become common (but are not present in all mylonites). The deepest rock of mafic origin, possibly an amphibolite in the Seve Nappe, was identified at $2314 \mathrm{~m}$. A transition from gneiss into lower-grade metasedimentary rocks occurs between 2345 and $2360 \mathrm{~m}$. The lower part of the drill core to TD is dominated by quartzites and metasandstones of unclear tectonostratigraphic position that are mylonitized to a varying degree. The rocks sampled in the lowermost part of the drill core are the thickest mylonites encountered, tens of metres thick and (again) rich in garnet.

The COSC-1 drill core is archived at the Core Repository for Scientific Drilling at the Federal Institute for Geosciences and Natural Resources (BGR), Wilhelmstr. 25-30,

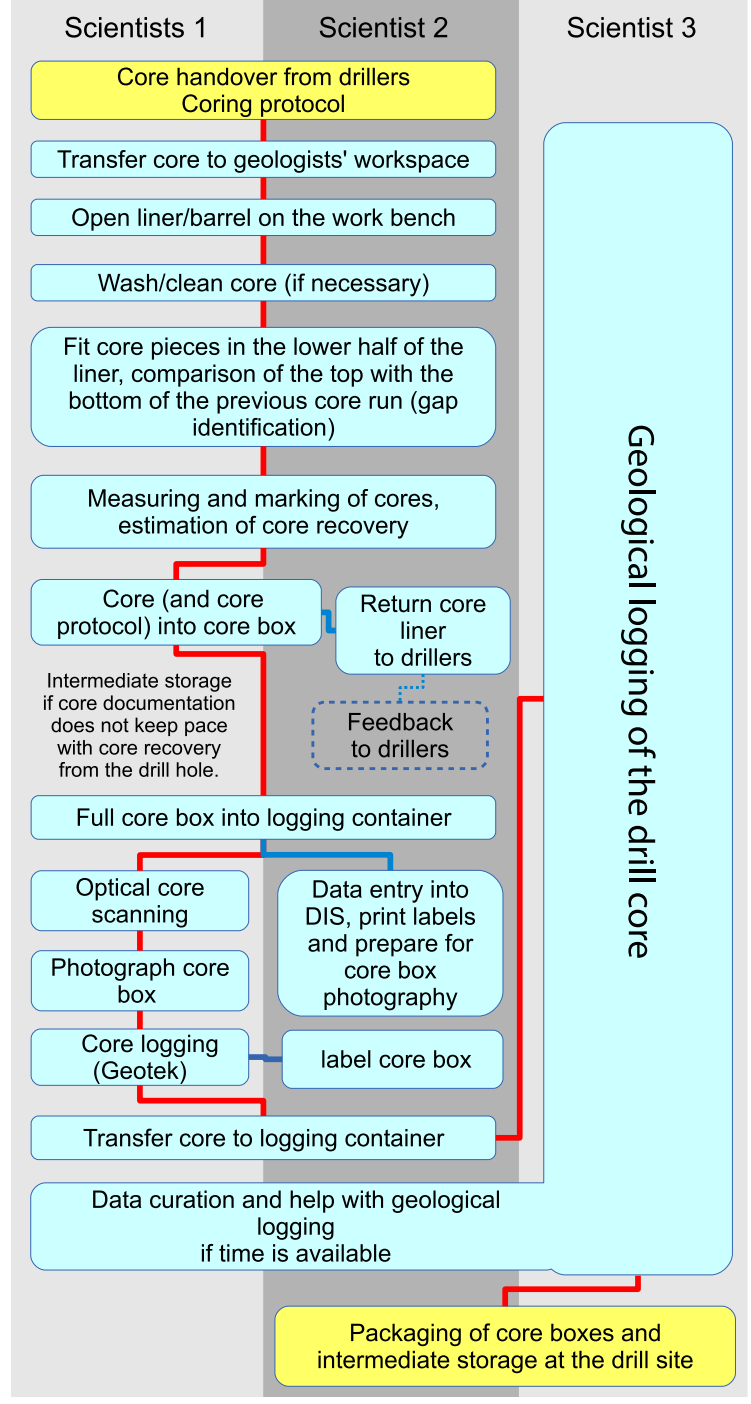

Figure 9. Flowchart over the COSC-1 drill core processing workflow.

13593 Berlin (Spandau), Germany. The first sampling party was held from 2 to 6 February 2015 at the core repository, where samples that amount to ca. $110 \mathrm{~m}$ total length were taken for laboratory investigations.

\section{Basic data}

The COSC-1 basic data with detailed documentation are available at doi:10.1594/GFZ.SDDB.ICDP.5054.2015 (Lorenz et al., 2015b) and include the following:

- technical data acquired at the drill rig;

- drill core metadata including the number of core run, depth, length of core run, sections, length of sections, core recovery, core orientation (where applicable) and the location of sections in core boxes; 


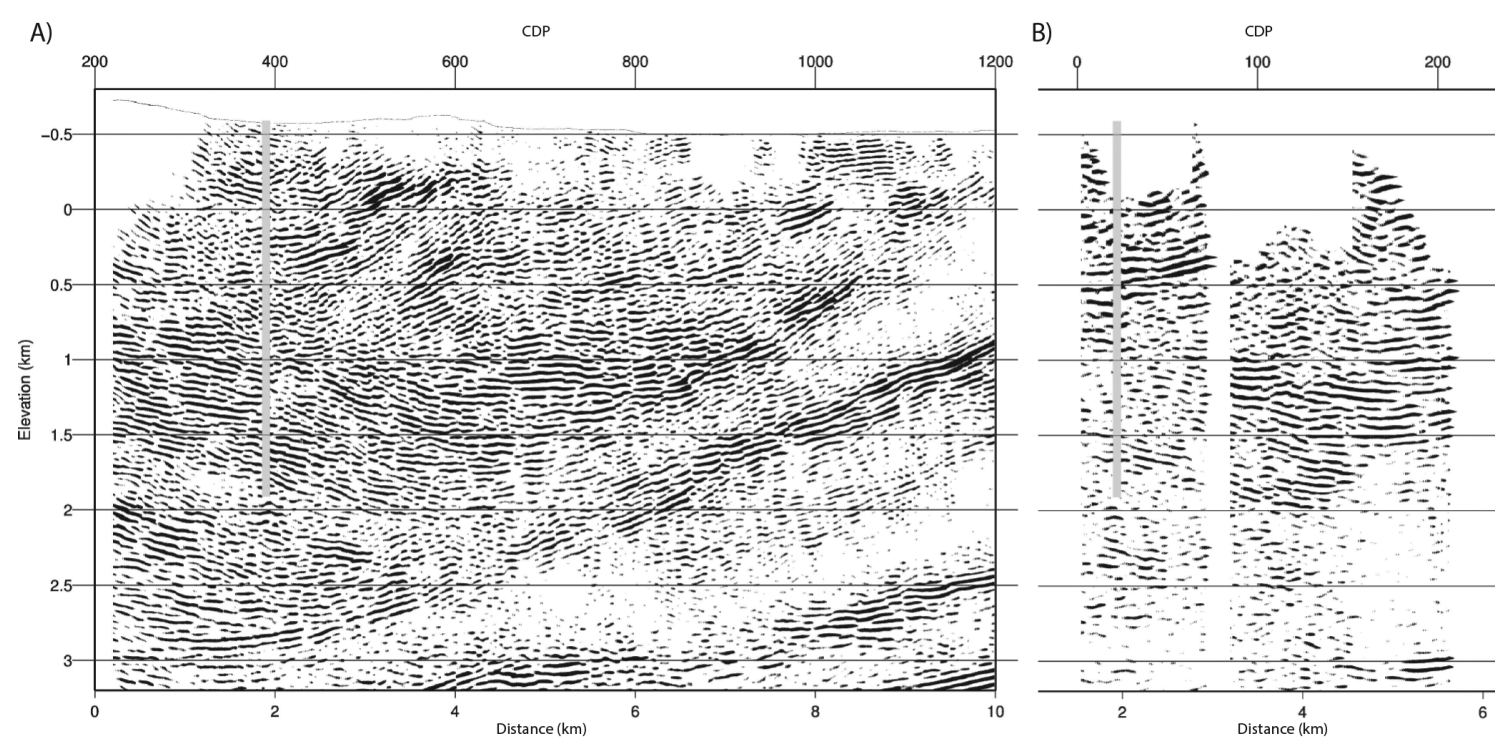

Figure 10. Seismic data from the pre-drilling seismic survey (a) as in Hedin et al. (2012) (b) reprocessed with a 3-D geometry over the crooked acquisition line. The grey vertical line indicates the location of the COSC-1 drill hole.

- the geological description of the drill core;

- unrolled core scans;

- core box images;

- geophysical parameters of the drill core: density, P wave velocity and magnetic susceptibility; the sensors of the MSCL were calibrated every day, but problems were observed (please refer to the full operational report);

- XRF geochemical data. For details refer to Sjöqvist et al. (2015);

- mud parameters;

- mud gas analyses (OLGA) for a nearly complete depth profile was compiled for the interval from 662 to $2490 \mathrm{~m}$ depth;

- downhole logging data from Lund University and ICDP OSG.

\section{Preliminary scientific assessment}

The COSC- 1 drill core provides a complete and unique geological section through the lower part of the Lower Seve Nappe and into the underlying thrust zone. The geological description of the drill core while drilling was difficult, with rotating personnel and field expertise that is not readily applicable to the drill core. Thus, the geological description of the drill core will be revised, based on the XRF survey and dedicated geochemical and mineralogical investigations. In anticipation of detailed investigations by the COSC science team, a couple of direct observations concerning the geology can be made. The gneisses of the Lower Seve Nappe are more homogenous than expected, in principle similar from the surface to $>2000 \mathrm{~m}$, amphibolite gneisses, felsic gneisses, calcsilicate gneisses dominating at different levels. A major surprise is the thickness of the thrust zone at the bottom of the Seve Nappe. About $800 \mathrm{~m}$ below the first shear bands and mylonites, its lower boundary was not reached. However, high-grade gneisses had passed into metasandstones, indicating that the drill hole had either entered an underlying unit or a tectonic sliver of it. Close to the bottom of the drill hole, mylonites in metasandstones contain a large proportion of garnet of considerable size (occasionally up to $1 \mathrm{~cm}$ ). This suggests metamorphic conditions that support garnet growth in the deformation zones late during thrusting.

The integrated interpretation of the geophysical and geological data before drilling was to a large extent confirmed, with the exception of the lower part of the drill hole. Twodimensional crooked line processing of the pre-drilling seismic survey over the COSC-1 site (Hedin et al., 2012) showed a highly reflective unit to be present from the near surface down to about $2.2 \mathrm{~km}$ (Fig. 10a). Correlation of this reflective unit, and the less reflective rock below it, to the boundary between the Seve Nappe Complex and the Ordovician turbidites about $9 \mathrm{~km}$ to the east of the COSC-1 site suggested that the high reflectivity was a characteristic of the Seve Nappe Complex itself. Later sparse 3-D processing of the crooked line data indicated significant lateral variability in the reflectivity. At the location of the COSC-1 borehole it appeared that the rock was most reflective in the uppermost $1 \mathrm{~km}$ with a rather distinct reflection originating at about $900 \mathrm{~m}$ depth (Fig. 10b). A gently east-dipping reflec- 
A)

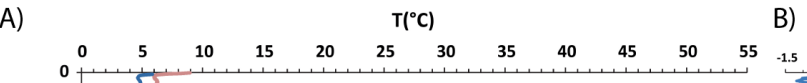

B)

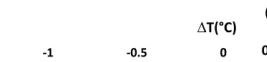

C) Heat generation $\left(\mu \mathrm{w} / \mathrm{m}^{3}\right)$
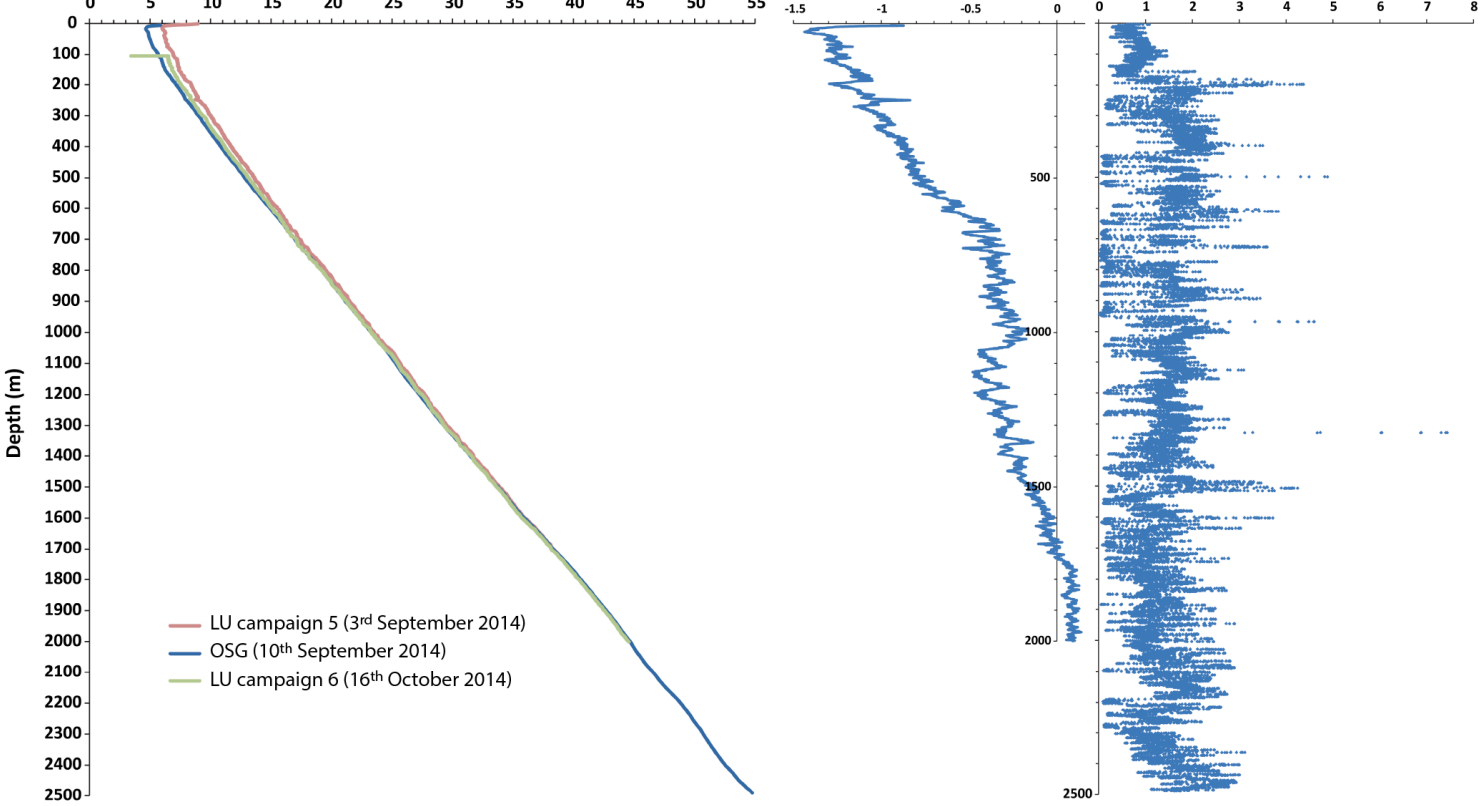

Figure 11. (a) Post-drilling temperature logs. Note gradual cooling (i.e. thermal re-equilibration) of the uppermost section of the borehole early in September 2014. The log measured in October is affected by post-drilling operations. (b) Temperature variations $(\Delta T)$ in the COSC1 drill hole from 3 until 10 September 2014. (c) Heat generation rates as derived from the spectral gamma log measured in the COSC-1 drill hole.

tion coming from about $2.1 \mathrm{~km}$ depth was thought to represent the base of the Seve Nappe Complex. The uppermost $500 \mathrm{~m}$ was poorly imaged due to the acquisition geometry. Potential field modelling (Hedin et al., 2014) also indicated the base of the Seve Nappe Complex to be at about $2 \mathrm{~km}$ depth at the COSC-1 site, consistent with the seismic data.

Preliminary analyses of the geophysical logging data and the geophysical core parameters show that the upper $1000 \mathrm{~m}$ contain the largest proportion of thicker amphibolite units (>15 m). The interval 1000 to $1800 \mathrm{~m}$ also contains a significant proportion of amphibolite, but the units are generally much thinner than above $1000 \mathrm{~m}$. Below $1800 \mathrm{~m}$, amphibolites are much less common. It is likely that it is the contrast in velocity and density between amphibolite and gneiss that is generating much of the reflectivity within the Seve Nappe Complex. Given that the average velocity of the complex is $6000 \mathrm{~m} \mathrm{~s}^{-1}$ and that the dominant frequency in the surface seismic data is $70-80 \mathrm{~Hz}$, the layers which are on the order of $20 \mathrm{~m}$ thick will generate the strongest reflections due to tuning. This is consistent with observations on the 3-D sparse processed data, which indicate the upper $1000 \mathrm{~m}$ to have higher-amplitude reflections in the COSC-1 area (Fig. 10b). The extensive post-drilling seismic survey will help to better define the geometry of the base of the Seve Nappe Complex in the vicinity of the COSC-1 borehole. The combined use of surface and borehole seismics will provide true 3-D coverage around the borehole and allow better resolution imaging at depth.
In a pre-drilling survey in 2012, the temperature of 18 abandoned mining boreholes was logged down to $100-200 \mathrm{~m}$. The temperature gradients were expectedly low and constrained the average ground temperatures to $\sim 4{ }^{\circ} \mathrm{C}$ at elevations corresponding to the COSC- 1 drill site $(\sim 500 \mathrm{~m}$ a.s.l.). Six temperature logs and one spectral gamma $\log$ were acquired after drilling was finished. However, three of the temperature logs were measured only 4 days after a pumping test, and other post-drilling operations were conducted in the hole. These logs show signs of temperature disturbances (Fig. 11a). A fourth temperature log acquired between $1600 \mathrm{~m}$ and TD shows a surprising offset with respect to all other measured temperature profiles. Only two temperature logs recorded respectively 6 and 13 days after final cleaning of the drill hole can give some insights on the expected steady state (Fig. 11a). The relatively slow temperature recovery observed between $\sim 1600$ and $2000 \mathrm{~m}$ depth (Fig. 11b) suggests negligible deviations from true formation temperatures along this specific depth interval and an uncorrected average gradient of $\sim 20^{\circ} \mathrm{C} \mathrm{km}^{-1}$. A preliminary estimation of heat generation rates based on the spectral gamma log indicates moderate heat production in the penetrated rocks (Fig. 11c). The sharp spikes in the heat generation profile are mostly related to highly radioactive pegmatite dykes. Future temperature measurements in the COSC-1 drill hole will include the installation of a $2.5 \mathrm{~km}$ distributed temperature sensing optical fibre in 2015 . Thermal property measurements were conducted up to four times on 24 core sam- 
ples coming from 5 different depth ranges using a thermal conductivity scanning device. Thermal and hydraulic properties are planned to be measured on 100 core samples. Ten representative samples will be shared for laboratory comparisons.

Hydrogeological tests were conducted during a drilling break at $1616 \mathrm{~m}$ and at TD. COSC-1 provided the opportunity to introduce a hydraulic test with negligible impact on the drilling schedule and the potential to provide important and accurate information on in situ hydraulic conductivities on both high- and low-transmissivity zones already during the drilling period. The particular testing method used was the flowing fluid electric conductivity (FFEC) logging method, which is capable of identifying large and small hydraulically active zones and provides data that can be used to estimate their transmissivity values and local formation water salinity (Tsang et al., 1990; Tsang and Doughty, 2003; Doughty et al., 2013). Based on FFEC logging, eight hydraulically active zones between $300 \mathrm{~m}$ and TD were identified. Transmissivity values are very low and range over 1 order of magnitude.

Due to technical problems and strategic decisions, deep biosphere research was restricted to drill core samples taken directly after opening of the inner tube. ATP and DNA swab samples were taken where the on-site science team encountered open fractures in the drill core. These samples are successively being processed and analysed. However, the complete equipment necessary for dedicated core drilling for microbiological research was adopted to "Riksriggen" and tested during the drilling operations and, thus, can easily be deployed in future projects.

\section{Conclusions}

The drilling of COSC-1 was very successful and provided the scientific community with nearly complete and unique sample material from a high-grade metamorphic nappe and its basal thrust zone, and with access to a largely uncased drill hole. Questions that originate from the COSC-1 drilling are the nature and tectonostratigraphic position of the seemingly lower-grade metamorphic rocks close to the bottom of the drill hole and how they relate to the intercalated garnetiferous mylonites. Did the garnet grow before and/or during deformation? What is the protolith of the mylonites?

COSC-1 research will continue during the coming years. In the meantime, the planning for COSC-2 has already begun: to drill through the basal Caledonian detachment into the basement of the Fennoscandian Shield.

Acknowledgements. COSC-1 was financed by the International Continental Scientific Drilling Program (ICDP) and the Swedish Research Council (VR - Grant 2013-94).

The Geological Survey of Sweden (SGU) supported the project with data acquisition over the target area during the planning phase and with in-kind contributions during the operational phase. In R \& D collaborations, Devico AS supplied a core orientation tool for NQ drilling and borehole orientation data, and Minalyze AB scanned the whole drill core with their new XRF scanner (cf. Sjöqvist et al., 2015). The ICDP Operational Support Group (OSG) provided training and practical help.

This project would never have been possible without the help of all the volunteers, who did a great job. Many thanks to the drilling team for a superb drill hole and core to almost $2500 \mathrm{~m}$ despite technical problems and the sometimes seemingly endless succession of nights and days with pipe handling. A full list of personnel is available in the operational report at doi:10.2312/ICDP.2015.002.

Edited by: T. Wiersberg

Reviewed by: A. Lepland and two anonymous referees

\section{References}

Andréasson, P. G. and Gee, D. G.: The Baltica-Iapetus boundary in the Scandinavian Caledonides and a revision of the Middle and Upper Allochthons, in: International Geological Congress, Abstracts, vol. 33, 2008.

Andréasson, P. G. and Gorbatschev, R.: Metamorphism in extensive nappe terrains: a study of the central Scandinavian Caledonides, Geol. Fören. Stockh. Förh., 102, 335-357, 1980.

Arnbom, J. O.: Metamorphism of the Seve nappes at Areskutan, Swedish Caledonides, edited by: Gee, D. G., Gorbatschev, R., and Ramberg, H., Geol. Fören. Stockh. Förh., 102, Part 4, 359371, doi:10.1080/11035898009454493, 1980.

Bergman, S. and Sjöström, H.: Accretion and lateral extension in an orogenic wedge: evidence from a segment of the Seve-Köli terrane boundary, central Scandinavian Caledonides, J. Struct. Geol., 19, 1073-1091, doi:10.1016/S0191-8141(97)00028-X, 1997.

Doughty, C., Tsang, C.-F., Yabuuchi, S., and Kunimaru, T.: Flowing fluid electric conductivity logging for a deep artesian well in fractured rock with regional flow, J. Hydrol., 482, 1-13, doi:10.1016/j.jhydrol.2012.04.061, 2013.

Erzinger, J., Wiersberg, T., and Zimmer, M.: Real-time mud gas logging and sampling during drilling, Geofluids, 6, 225-233, doi:10.1111/j.1468-8123.2006.00152.x, 2006.

Gee, D. G.: Nappe displacement in the Scandinavian Caledonides, Tectonophysics, 47, 393-419, doi:10.1016/00401951(78)90040-9, 1978.

Gee, D. G., Kumpulainen, R., Roberts, D., Stephens, M. B., and Zachrisson, E.: Scandinavian Caledonides, Tectonostratigraphic Map, 1985.

Gee, D. G., Fossen, H., Henriksen, N., and Higgins, A. K.: From the Early Paleozoic Platforms of Baltica and Laurentia to the Caledonide Orogen of Scandinavia and Greenland, Episodes, 31, 44$51,2008$.

Gee, D. G., Juhlin, C., Pascal, C., and Robinson, P.: Collisional Orogeny in the Scandinavian Caledonides (COSC), GFF, 132, 29-44, doi:10.1080/11035891003759188, 2010.

Greiling, R. O., Garfunkel, Z., and Zachrisson, E.: The orogenic wedge in the central Scandinavian Caledonides: Scandian structural evolution and possible influence on the foreland basin, GFF, 120, 181-190, 1998. 
Gromet, L. P., Sjöström, H., Bergman, S., Claesson, S., Essex, R. M., Andreasson, P. G., and Albrecht, L.: Contrasting ages of metamorphism in the Seve nappes: $\mathrm{U}-\mathrm{Pb}$ results from the central and northern Swedish Caledonides, Geol. Fören. Stockh. Förh., 118, A36-A37, 1996.

Hedin, P., Juhlin, C., and Gee, D. G.: Seismic imaging of the Scandinavian Caledonides to define ICDP drilling sites, Tectonophysics, 554-557, 30-41, doi:10.1016/j.tecto.2012.05.026, 2012.

Hedin, P., Malehmir, A., Gee, D. G., Juhlin, C., and Dyrelius, D.: 3D interpretation by integrating seismic and potential field data in the vicinity of the proposed COSC-1 drill site, central Swedish Caledonides, Geol. Soc. Lond. Spec. Publ., 390, 301319, doi:10.1144/SP390.15, 2014.

Janák, M., van Roermund, H., Majka, J., and Gee, D.: UHP metamorphism recorded by kyanite-bearing eclogite in the Seve Nappe Complex of northern Jämtland, Swedish Caledonides, Gondwana Res., 23, 865-879, doi:10.1016/j.gr.2012.06.012, 2013.

Juhojuntti, N., Juhlin, C., and Dyrelius, D.: Crustal reflectivity underneath the Central Scandinavian Caledonides, Tectonophysics, 334, 191-210, doi:10.1016/S0040-1951(00)00292-4, 2001.

Klonowska, I., Janák, M., Majka, J., Froitzheim, N., and Gee, D. G.: The UHP metamorphic Seve Nappe Complex of the Swedish Caledonides - a new occurrence of the microdiamond-bearing gneisses and their exhumation, Geophys. Res. Abstr., vol. 17, EGU2015-11609, European Geosciences Union, Vienna, 2015.

Kulling, O.: Bergbyggnaden inom Björkvattnet - Virisen-området i Västerbottensfjällens centrala del, Geol. Fören. Stockh. Förh., 55, 167-422, doi:10.1080/11035893309450934, 1933.

Kumpulainen, R.: Upper Proterozoic stratigraphy and depositional environments of the Tossasfjället Group, Särv Nappe, southern Swedish Caledonides, Geol. Foren. Stockh. Forh., 102, 531-550, 1980.

Ladenberger, A., Be'eri-Shlevin, Y., Claesson, S., Gee, D. G., Majka, J., and Romanova, I. V.: Tectonometamorphic evolution of the Åreskutan Nappe - Caledonian history revealed by SIMS U-Pb zircon geochronology, Geol. Soc. Lond. Spec. Publ., 390, 337-368, doi:10.1144/SP390.10, 2014.

Lorenz, H., Gee, D., and Juhlin, C.: The Scandinavian Caledonides - Scientific Drilling at Mid-Crustal Level in a Palaeozoic Major Collisional Orogen, Sci. Dril., 11, 60-63, doi:10.5194/sd-11-602011, 2011.

Lorenz, H., Gee, D. G., Larionov, A. N., and Majka, J.: The Grenville-Sveconorwegian Orogen in the High Arctic, Geol. Mag., 149, 875-891, doi:10.1017/S0016756811001130, 2012.

Lorenz, H., Rosberg, J.-E., Juhlin, C., Bjelm, L., Almqvist, B. S. G., Berthet, T., Conze, R., Gee, D. G., Klonowska, I., Pascal, C., Pedersen, K., Roberts, N. M. W., and Tsang, C.-F.: Operational Report about Phase 1 of the Collisional Orogeny in the Scandinavian Caledonides scientific drilling project (COSC-1), GFZ German Research Center for Geosciences, doi:10.2312/ICDP.2015.002, 2015a.
Lorenz, H., Rosberg, J.-E., Juhlin, C., Bjelm, L., Almqvist, B. S. G., Berthet, T., Conze, R., Gee, D. G., Klonowska, I., Pascal, C., Pedersen, K., Roberts, N. M. W., and Tsang, C.-F.: COSC-1 operational report - Scientific data sets, GFZ German Research Center for Geosciences, doi:10.1594/GFZ.SDDB.ICDP.5054.2015, 2015b.

Majka, J., Rosén, Å., Janák, M., Froitzheim, N., Klonowska, I., Manecki, M., Sasinková, V., and Yoshida, K.: Microdiamond discovered in the Seve Nappe (Scandinavian Caledonides) and its exhumation by the "vacuum-cleaner" mechanism, Geology, 42, 1107-1110, G36108.1, doi:10.1130/G36108.1, 2014.

Mangelsdorf, K. and Kallmeyer, J.: Integration of Deep Biosphere Research into the International Continental Scientific Drilling Program, Sci. Dril., 10, 46-55, doi:10.5194/sd-10-462010, 2010.

Palm, H., Gee, D. G., Dyrelius, D., and Björklund, L.: A reflection seismic image of Caledonian structure in central Sweden, Sveriges geologiska undersökning, Uppsala, 1991.

Root, D. and Corfu, F.: U-Pb geochronology of two discrete Ordovician high-pressure metamorphic events in the Seve Nappe Complex, Scandinavian Caledonides, Contrib. Mineral. Petrol., 163, 769-788, doi:10.1007/s00410-011-0698-0, 2012.

Sjöqvist, A. S. L., Arthursson, M., Lundström, A., Calderón Estrada, E., Inerfeldt, A., and Lorenz, H.: An innovative optical and chemical drill core scanner, Sci. Dril., 19, 13-16, doi:10.5194/sd-19-13-2015, 2015.

Sjöström, H.: The Seve-Köli Nappe Complex of the HandölStorlien-Essandsjöen area, Scandinavian Caledonides, Geol. Foren. Stockh. Förh., 105, 1-26, 1983.

Strömberg, A. G.: On the tectonics of the Caledonides in the southwestern part of the County of Jämtland, Sweden, Almqvist \& Wicksell, Uppsala, 1961.

Tsang, C.-F. and Doughty, C.: Multirate flowing fluid electric conductivity logging method, Water Resour. Res., 39, 1354, doi:10.1029/2003WR002308, 2003.

Tsang, C.-F., Hufschmied, P., and Hale, F. V.: Determination of fracture inflow parameters with a borehole fluid conductivity logging method, Water Resour. Res., 26, 561-578, doi:10.1029/WR026i004p00561, 1990.

Van Roermund, H. L. M.: Eclogites of the Seve Nappe, central Scandinavian Caledonides, in: The Caledonide Orogen; Scandinavia and related areas, edited by: Gee, D. G. and Sturt, B. A., 873-886, John Wiley \& Sons, Chichester, 1985.

Wiersberg, T. and Erzinger, J.: Chemical and isotope compositions of drilling mud gas from the San Andreas Fault Observatory at Depth (SAFOD) boreholes: Implications on gas migration and the permeability structure of the San Andreas Fault, Chem. Geol., 284, 148-159, doi:10.1016/j.chemgeo.2011.02.016, 2011.

Williams, I. S. and Claesson, S.: Isotopic evidence for the Precambrian provenance and Caledonian metamorphism of high grade paragneisses from the Seve Nappes, Scandinavian Caledonides, Contrib. Mineral. Petrol., 97, 205-217, doi:10.1007/BF00371240, 1987. 